\title{
DAMPAK PEMBELAJARAN LURING DI MASA PANDEMI TRHADAP HASIL BELAJAR KOGNITIF SISWA PADA MATA PELAJARAN IPS
}

\author{
Zakarias Iwan Kristiono', Amin Mustajab $^{2}$ \\ SMP Negeri 01 Entikong, STKIP Melawi, \\ ni.faguh@gmail.com,amin.mustajab@stkipmelawi.ac.id
}

\begin{abstract}
ABSTRAK
Menyebarnya virus covid-19 di Indonesia mengakibatkan pembelajaran tatap muka dibatasi dan dialihkan menjadi PJJ. PJJ yang diterapkan adalah pembelajaran luar jaringan (luring). Tujuan utama penelititan ini untuk melihat dampak pembelajaran luring dengan memberikan tugas memberikan terhadap hasil belajar kognitif pada mata pelajaran IPS. Kuantitatif desain one group pretest-posttest digunakan pada penelitian ini. Siswa kelas VII SMP Negeri 01 Entikong merupakan populasi penelitian ini. Jumlah sampel pada penelitian ini 34 siswa. Instrumen penelitian ini terdiri dari soal uraian singkat sebanyak 5 soal terdiri dari 2 soal c1, 2 soal c2 dan 1 soal c3. Data penelitian diuji normalitasnya menggunakan uji statistik Kolmogorov-Smirnov. Hipotesis diuji menggunakan uji statistik Wilcoxon dikarenakan data pretest dan posttest berdistribusi tidak normal. Hasil uji sattistik Wilcoxon menunjukan bahwa tidak terdapat perbedaan rerata hasil belajar siswa sebelum dan sesudah mengikuti pembelajaran luring dengan memberikan tugas.
\end{abstract}

Kata Kunci: Pembelajaran Luring, Hasil belajar, Masa Pandemi.

\section{ABSTRACT}

Goal of this study is to see whether offline learning by giving assignments has an impact on cognitive learning outcomes in social studies subjects. Quantitative method with one group pretest-posttest design. Seventh grade students of SMP Negeri 01 Entikong are the population of this study. the sample in this study amounted to 34 students. The instrument of this research consisted of a short description of 5 questions consisting of 2 questions c1, 2 questions c2 and 1 question c3. Data normality was tested using the Kolmogorov-Smirnov statistic test. Hypothesis testing was carried out using the Wilcoxon statistical test because the pretest and posttest data were not normally distributed. The results of the Wilcoxon statistical test showed that there was no difference in the average student learning outcomes before and after taking offline learning by giving assignments

Keywords: Offline Learning, Learning Outcomes, Pandemic Period.

\section{A. PENDAHULUAN}

Akitivitas kegiatan pendidikan baik ditingkat dasar hingga perguruan tinggi dibatasi saat COVID-19 melanda Indonesia (Amin Mustajab et al., 2021). Coronavirus ini menimbulkan kendala bagi semua kalangan terutama dunia pendidikan, terutama bagi pelaksanaan kegiatan pembelajaran (Sari et al., 2021). Pembelajaran dapat diartikan sebagai kegiatan yang dilaksanakan dengan memberikan pendidikan dan pelatihan agar terjadi perubahan yang permanen (Sutriyani, 2020). Perlu metode yang tepat agar hasil belajar yang diinginkan 
dapat tercapai. Keberhasilan pendidikan diera pandemi dipengaruhi oleh, tingkat kesiapan sekolah, kesiapan orang tua, dan kesiapan guru. Kebutuhan siswa harus diperhatikan dalam memberikan pendidikan diera pandemi (Turmuzi \& Dasing, 2021). Kegiatan belajar yang dapat diterapkan selama masa pandemi adalah pembalajaran berbasis jaringan dan pembelajaran luar jaringan (luring) dan $e$ learning.

E-learning merupakan pendidikan yang ketika penerapannya memerlukan jaringan dan dilakukan tanpa tatap muka antara pengajar maupun peserta didik, jam dan materi pembelajaran yang sama seperti pembelajaran tatap muka (Harahap et al., 2021). Pembelajaran daring tidak membatasi waktu dan tempat kegiatan, memberikan kebebasan bagi siswa untuk menentukan waktu yang tepat berdasarkan keperluan siswa, diharapkan kemampuan untuk memahami materi menjadi lebih baik lagi dibandingkan belajar di dalam kelas (Rani, 2021). Elearning lebih memfokuskan pada kehati-hatian dan ketelitian peserta didik dalam memahami dan mengolah informasi yang diajarkan secara daring (Rahmawati et al., 2020).

Kekurangan penggunaan daring sulit membuat siswa fokus hal ini disebabkan oleh situasi serta keadaan tidak mendukung untuk proses pembelajaran (Rahmawati et al., 2020). Beberapa hambatan dapat terjadi selama penerapan pembelajaran daring diantaranya kendala sinyal (visual maupun audio) dan tidak adanya proses untuk mengecek apakah peserta didik memahami materi yang diajarkan (Yani \& Bernarda Teting, 2020). Selain itu ada peserta didik tidak mengerjakan soal yang diberikan dengan alasan tidak memiliki gawai yang mendukung. Selain itu keterbatasan ketersediaan gawai yang dimiliki mengakibatkan peserta didik harus bergiliran antar keluarganya yang lain, tidak terdapat sinyal di tempat pesrta didik tinggal, jikapun ada peserta didik terkendala dengan tidak adanya pulsa yang memadai (Pratama \& Mulyati, 2020). Gawai menjadi alat pendukung utama selama pembelajaran daring karena tanpa adanya gawai pembelajaran tidak dapat terlaksana (Sulha, 2020). Solusi lainnya yang dapat di terapkan adalah pembelajaran luring.

Luring dapat diartikan sebagai pendidikan yang dilakukan secara tanpa tatap muka serta tidak menggunakan gawai dan jaringan internet (Muamar Al Qadri, 
2021). Pembelajaran luring dikerjakan melalui media buku, modul, dan bahan ajar di lingkungan sekitar sekolah baik dengan media audio maupun audio visual (Solong, 2021). Pembelejaran luring dapat diterapkan melalui pembelajaran doorto-door, siswa hadir langsung ke sekolah untuk mengambil tugas dan siswa dapat masuk sekolah degan jadwal bergantian saat pandemi (Putri et al., 2021).

Metode pemberian tugas (assignment methods) merupakan kegiatan pembelajaran memberikan tugas-tugas kepada peserta didik (Zuraida et al., 2021). Pembelajaran luring dapat dilaksanakan dengan memberikan tugas secara terstruktur memberikan kesempatan kepada peserta didik untuk menggali informasi sesuai melalui semua sumber daya yang tersedia. Hal ini sejalan dengan temuan dari Ekantini ( 2020) bahwa hasil pembelajaran siswa pada pembelajaran luring lebih tinggi dibandingkan dengan pembelajaran daring. Temuan dari Zuraida et al. (2021) bahwa pembelajaran luring dengan pemberian tugas dapat meningkatkan prestasi siswa.

Penerapan pembelajaran dalam jaringan memiliki kendala bila diterapkan pada daerah yang tidak memiliki koneksi jaringan internet. Selain itu, tidak semua siswa memiliki gawai untuk melaksanakan pembelajaran berbasis jaringan. Disisi lain, pembelajaran harus tetap dilaksanakan selama masa pandemi ini dengan menerapkan protokol kesahatan dan sosial distancing. Oleh karena itu, penelitian ini ingin melihat dampak pembelajaran luring menggunkan metode pemberian tugas terhadap hasil belajar kogitif pada mata pelajaran IPS. Hipotesis pada penelitian ini terdapat perbedaan hasil belajar sisiwa sebelum dan setelah mengikuti pembelajaran luring menggunakan tugas tambahan.

\section{B. METODE}

Metode kuantitatif diterapkan pada penelitian ini. One-group pretest-postest design yang digunakan pada penelitian ini. Populasi peneilitian ini siswa kelas VII SMP Negeri 01 Entikong. Sampel penelitian ini terdiri dari 34 siswa kelas VII A SMP Negeri 01 Entikong. instrumen penelitian yang digunakan pada penelitian ini teridiri dari tes tertulis. Tes tertulis yang digunakan berupa soal esai sebanyak 5 soal. Instrumen tes hasil belajar kognitif berada pada level C1, C2 dan C3. Instrumen penelitian diuji validasi isinya mengguakan bantuan tenaga ahli sebanyak 2 orang ahli. Uji prasyarat untuk melihat apakah data pre-test dan post- 
test berdistribusi normal dilakukan menggunakan uji normalitas menggunakan uji Kolmogorov-Smirnov. Untuk melihat apakah pembelajaran memberikan dampak terhadap hasil belajar kognitif mata pelajaran IPS digunakan uji statistik paired sampel t-test jika data berdistribusi normal. Apabila dari hasil uji normalitas data berdistribusi tidak normal maka uji statistik dilakukan menggunakan uji statistik Wilcoxon. Uji statistik dilakukan dengan bantuan aplikasi uji statistik.

\section{HASIL DAN PEMBAHASAN}

Tabel 1

Hasil uji validasi oleh ahli

\begin{tabular}{|c|c|c|c|c|c|c|}
\hline \multirow[t]{2}{*}{ Soal no } & \multicolumn{3}{|c|}{ Pre-test } & \multicolumn{3}{|c|}{ Post-test } \\
\hline & Validator 1 & Validator 2 & Rata-rata & Validator 1 & Validator 2 & Rata-rata \\
\hline 1 & 2,5 & 3 & 2,75 & 2 & 3 & 2,5 \\
\hline 2 & 2,7 & 2 & 2,35 & 2,4 & 2 & 2,2 \\
\hline 3 & 2 & 2 & 2 & 2,4 & 3 & 2,7 \\
\hline 4 & 2,5 & 3 & 2,75 & 3 & 3 & 3 \\
\hline 5 & 2 & 2 & 2 & 2 & 2 & 2 \\
\hline \multicolumn{3}{|c|}{ Rata-rata total Pre-test } & 2,37 & \multicolumn{2}{|c|}{ Rata-rata total Post-test } & 2,48 \\
\hline
\end{tabular}

Hasil uji valiadasi isi oleh 2 orang ahli menyatakan instrument penelitian berupa soal esai sebanyak 5 soal berada pada kategori baik dapat digunakan dengan sedikit revisian. Soal pre-test mendapat rerata skor sebesar 2,37. Soal post-test mendapatkan rerata skor sebesar 2,48. Setelah direvisi sesuai dari pendapat yang diberikan oleh validator, kemudian soal dapat digunakan untuk mengetahui hasil belajar kognitif siswa.

Tabel 2

Hasil Tests of Normality

\begin{tabular}{lccc}
\hline \hline & \multicolumn{3}{c}{ Kolmogorov-Smirnov $^{\boldsymbol{a}}$} \\
\cline { 2 - 4 } pretest & Statistic & Df & Sig. \\
\hline posttest &, 239 & 34 &, 000 \\
\hline a. Lilliefors &, 186 & 34 &, 004 \\
\hline
\end{tabular}

Hasil uji normalitas menunjukan bahwa baik data nilai sebelum dan sesduah berdistribusi tidak normal. Pada Tabel 2. hasil uji Kolmogorov-Smirnov nilai sig. pre-test dan post-test $\leq 0,05$. Nilai sig. pretes sebesar 0,000 dan nilai sig post-test sebesar 0,004. Oleh karena itu, untuk menguji hipotesis penilitian ini dilakukan bukan dengan uji statistik parametrik. Uji statistik yang digunakan ialah uji Wilcoxon. 
Tabel 3

Hasil uji wilcoxon menggunakan SPSS Test Statistics ${ }^{\mathrm{a}}$

\begin{tabular}{lrr}
\hline \hline \multicolumn{1}{c}{ posttest - pretest } \\
\hline $\mathbf{Z}$ & $-1,181^{\mathrm{b}}$ \\
\hline Asymp. Sig. (2-tailed) &, 238 \\
\hline a. Wilcoxon Signed Ranks Test & \\
b. Based on negative ranks. &
\end{tabular}

Berdasarkan hasil uji Wilcoxon pada Tabel 3. menggunakan aplikasi bantuan statistik SPSS nilai sig. (2-tailed) sebesar 0,238. Nilai uji statistik Wilcoxon sig. (2-tailed) $\geq 0,05$, sehingga h0 diterima dan h1 tidak diterima. Hasil uji statistik Wilcoxon menunjukan tidak terdapat perbedaan scara statistik antara hasil sebelum dan sesudah perlakuan. Meskipun tidak terdapat perbedaan secara statistik hasil pre-test dan post-test tetapi rerata nilai pos-test siswa lebih tinggi dibandingkan dengan rerata nilai pre-test siswa. Rerata hasil pre-test siswa sebesar 80,05 sedangkan hasil post-test siswa sebesar 81,32.

Tabel 4

Ranks

\begin{tabular}{llccc}
\hline \hline & & N & Mean Rank & Sum of Ranks \\
\hline posttest - pretest & Negative Ranks & $12^{\mathrm{a}}$ & 9,92 & 119,00 \\
\cline { 2 - 5 } & Positive Ranks & $13^{\mathrm{b}}$ & 15,85 & 206,00 \\
\cline { 2 - 5 } & Ties & $9^{\mathrm{c}}$ & & \\
\cline { 2 - 5 } & Total & 34 & & \\
\hline
\end{tabular}

a. posttest < pretest

b. posttest $>$ pretest

c. posttest $=$ pretest

Berdasarkan Tabel 4. terdapat 12 atau sebesar 35,29\% orang siswa yang mengalami penurunan hasil tes, 13 orang siswa yang mengalami peningakatan hasil tes dan 9 orang siswa yang hasilnya tetap. Salah penyebab terjadinya penurunan hasil belajar ini adalah metode pembelajaran (Nabillah \& Abadi, 2019), jika metode mengajar guru yang kurang baik akan mempengaruhi belajar siswa yang tidak baik pula (Aisyah et al., 2017). Pembelajaran luring dengan pemberian tugas ini menuntut kemandirian siswa untuk memahami materi pembelajaran secara mandiri (Makur et al., 2021), hal ini menjadi kendala utama bagi siswa dengan kemampuan kognitif yang rendah (Magdalena \& Yestiani, 2020). Anak murid dengan kemampuan kogitif yang rendah mengalami keslitan untuk memahami materi pembelajaran yang disampaikan bahkan pada kelas daring dimana masih dapat menyampaikan 
materi secara langsung. Hal ini sejalan dengan temuan dari Jannah (2021) sebagian besar anak didik dengan pengetahuan awal sangat kurang mengenai bahan ajar menyebabkan menrunkan daya tarik untuk mengulang materi.

Selain itu, pembelajaran daring dengan memberikan tugas juga harus memperhatikan dampak terhadap psikologi kepada siswa. Hal ini sejalan dengan temuan penelitian Mustakim (2020) terdapat keluhan psikologis selama pembelajaran dimasa pandemi. Keluhan psikologis ini dapat mempengaruhi hasil belajar siswa. Pelaksanaan pembelajaran luring dengan memberikan tugas seharusnya tetap mengedepankan penyampaian materi kepada siswa. Guru sebagai pendidik harus hadir memberikan arahan dan motivasi bagi anak murid yang mengalami kendala serta kendala dalam proses pembelajaran. Untuk meningkatkan efektivitas pembelajaran luring dan daring sebaiknya menyediakan rangkuman bahab pembelajaran yang rsederhana dan mengurangi memberikan bahan ajar dalam bentuk video (Turmuzi \& Dasing, 2021). Guru dan siswa dapat berdiskusi dan berinteraksi melalui forum diskusi terkait dengan permasalahan materi yang disampaikan ataupun jalannya pembelajaran yang dilakukan (Medida et al., 2020).

Berdasarkan Tabel 3. terdapat 13 atau sebesar 38,23\% orang siswa yang mengalami peningkatan hasil tes. Hal ini dapat terjadi karena kemadirian belajar siswa (Handarini, 2020) selama pandemi sudah terlatih saat penerapan pembelajaran luring dengan pemberian tugas (Munarti, 2020). Hal ini sejalan dengan temuan dari Makur et al. (2021) lebih dari 75\% mahasiswa menetapkan stategi belajar untuk mencapai tujuan belajar yang diinginkan. Serta temuan Kurniasari et al. (2020) yang menunjukan bahwa $76 \%$ siswa menjawab dan mengecek jawaban dari tugas yang diberikan sendiri tanpa didampingi orang tua. Kemandirian belajar dapat diarahkan untuk kemampuan berpikir, memilih strategi, dan motivasi yang berkelanjutan, tetapi juga harus membuat anak didik untuk menerapkannya dalam mengatasi masalah dengan efektif (Kusuma, 2020).

Proses pembelajaran yang terjadi selama masa pandemi menitik beratkan kemandirian belajar siswa. Bagi siswa dengan kemampuan kognitif dan kemandirian belajar rendah mengalami kesulitan dalam memahami materi 
pembelajaran. Guru sebagai pendidi harus dapat memfasilitasi siswa yang mengalami kendala tersebut. Guru dapat memanfatkan media serta teknologi untuk menyampaikan materi pembelajaran.

\section{KESIMPULAN}

Berdasarkan hasil dan pembahasan tidak terdapat perbedaan secara statistik hasil belajar kognitif siswa sebelum dan setelah mengikuti pembelajaran luring dengan memberikan tugas selama massa pandemi. Dengan kata lain, pembelajaran luring dengan memberikan tugas dapat dikatakan tidak efektif. Meskipun tidak terdapat perbedaan hasil belajar sebelum dan sesudah mengikuti pembelajaran luring, terdapat 38,23\% siswa yang mengalami peningkatan hasil belajar. Hal ini dikarenakan pembelajaran selama massa pandemi menuntut kemandirian siswa. Siswa yang memiliki kemandirian belajar dapat dengan mudah beradaptasi dalam pembelajaran luring sehingga dapat meningkatkan hasil belajar.

Disisi lain, terdapat $35,29 \%$ siswa yang mengalami penurunan hasil belajaran sebelum dan sesudah mengikuti pembelajaran luring dengan memberikan tugas. Hal ini dikarenakan siswa dengan kemampuan kognitif rendah memiliki kendala dalam memahami materi pembelajaran. Kemudian diperparah ketika kemadirian belajar siswa belum terlatih sehingga siswa tidak siap dalam menghadapi pembelajaran selama masa pandemi.

Pembelajaran dimasa pandemi harus memfasiliasi seluruh peserta didik utuk mencapai tujuan pembelajaran. Pembelajaran luring dengan memberikan tugas ini tidak memberikan perbedaan secara statistik sebelum dan sesudah mengikuti kelas pembelajaran. Guru perlu mempertimbangkan siswa dengan kemapuan kognitif dan kemandirian belajar rendah agar dapat memahami materi pembelajaran yang akan dicapai.

\section{DAFTAR PUSTAKA}

Aisyah, A., Jaenudin, R., \& Koryati, D. (2017). Analisis Faktor Penyebab Rendahnya Hasil Belajar Peserta Didik Pada Mata Pelajaran Ekonomi Di Sma Negeri 15 Palembang. PROFIT Kajian Pendidikan Ekonomi dan Ilmu Ekonomi, 4(1), 11.

Amin Mustajab, Syamsijulyanto, T., Zaky Tatsar, M., \& Rian Priyadi. (2021). Pemanfaatan Radio untuk Mengatasi Keterbatasan Jaringan Pada Pembelajaran Daring Selama Masa Pandemi. Dinamisia : Jurnal Pengabdian 
Kepada Masyarakat, 5(3). https://doi.org/10.31849/dinamisia.v5i3.4608

Ekantini, A. (2020). Efektivitas Pembelajaran Daring pada Mata Pelajaran IPA di Masa Pandemi Covid-19: Studi Komparasi Pembelajaran Luring dan Daring pada Mata Pelajaran IPA SMP. Jurnal Pendidikan Madrasah, 5, 7.

Handarini, O. I. (2020). Pembelajaran Daring Sebagai Upaya Study From Home (SFH)Selama Pandemi Covid 19. Jurnal Pendidikan Administrasi Perkantoran (JPAP), 8(3), 8.

Harahap, S. A., Dimyati, D., \& Purwanta, E. (2021). Problematika Pembelajaran Daring dan Luring Anak Usia Dini bagi Guru dan Orang tua di Masa Pandemi Covid 19. Jurnal Obsesi : Jurnal Pendidikan Anak Usia Dini, 5(2), 1825-1836. https://doi.org/10.31004/obsesi.v5i2.1013

Jannah, M. (2021). Pengaruh Pembelajaran Online Berbantuan Google Classroom Terhadap Hasil Belajar Siswa Sma Pada Materi Sistem Peredaraan Darah Pada Manusia. JRIP: Jurnal Riset dan Inovasi Pembelajaran, 1(1), 10.

Kurniasari, A., Pribowo, F. S. P., \& Putra, D. A. (2020). Analisis Efektivitas Pelaksanaan Belajar Dari Rumah (Bdr) Selama Pandemi Covid-19. Jurnal Review Pendidikan Dasar: Jurnal Kajian Pendidikan Dan Hasil Penelitian, 6(3), 8 .

Kusuma, D. A. (2020). Dampak Penerapan Pembelajaran Daring Terhadap Kemandirian Belajar (Self-Regulated Learning) Mahasiswa Pada Mata Kuliah Geometri Selama Pembelajaran Jarak Jauh Di Masa Pandemi Covid19. Teorema: Teori dan Riset Matematika, 5(2), 169. https://doi.org/10.25157/teorema.v5i2.3504

Magdalena, I., \& Yestiani, D. K. (2020). Rendahnya Perkembangan Mutu Hasil Belajar Siswa Sekolah Dasar Dengan Adanya Pembelajaran Online. EDISI : Jurnal Edukasi dan Sains, 2, 14.

Makur, A. P., Jehadus, E., Fedi, S., Jelatu, S., Murni, V., \& Raga, P. (2021). Kemandirian Belajar Mahasiswa dalam Pembelajaran Jarak Jauh Selama Masa Pandemi. Jurnal Pendidikan Matematika, 10, 12.

Medida, V. A., Safitri, Y. A., \& Normala, P. O. (2020). Dampak Masa Pandemi Covid-19 Terhadap Dinamika Pembelajaran Guru Ips Pada Siswa Smp. In Seminar Nasional Pendidikan IPS, 1(1), 8.

Muamar Al Qadri, S. W. (2021). Pengaruh Home Visit Method Terhadap Hasil Belajar Luring di Masa Pandemi COVID-19 Pada Mata Pelajaran Al Qur'an Hadits (Studi Kasus Siswa Kelas VIII MTS Jam'iyah Mahmudiyah Tanjung Pura Langkat). Continuous Education: Journal of Science and Research, 2(1), 61-71. https://doi.org/10.51178/ce.v2i1.187

Munarti, I. (2020). Peningkatan Hasil Belajar Siswa Di Smpn 3 Cepu Melalui 
Aplikasi Quipper School. Jurnal Pendidikan Bahasa Indonesia, 8, 10.

Mustakim, M. (2020). Efektivitas Pembelajaran Daring Menggunakan Media Online Selama Pandemi Covid-19 Pada Mata Pelajaran Matematika. Al asma: $\begin{array}{lllll}\text { Journal of Islamic } & \text { Education, } & \text { 2(1), }\end{array}$ https://doi.org/10.24252/asma.v2i1.13646

Nabillah, T., \& Abadi, A. P. (2019). Faktor Penyebab Rendahnya Hasil Belajar Siswa. Prosiding Seminar Nasional Matematika dan Pendidikan Matematika Sesiomadika 2019, 5.

Pratama, R. E., \& Mulyati, S. (2020). Pembelajaran Daring dan Luring pada Masa Pandemi Covid-19. Gagasan Pendidikan Indonesia, 1(2), 49. https://doi.org/10.30870/gpi.v1i2.9405

Putri, A. P., Rahhayu, R. S., Suswandari, M., \& Ningsih, P. A. R. (2021). Strategi Pembelajaran Melalui Daring Dan Luring Selama Pandemi Covid-19 Di Sd Negeri Sugihan 03 Bendosari. Prima Magistra: Jurnal Ilmiah Kependidikan, 2(1), 1-8. https://doi.org/10.37478/jpm.v2i1.728

Rahmawati, N. R., Rosida, F. E., \& Kholidin, F. I. (2020). Analisis Pembelajaran Daring Saat Pandemi Di Madrasah Ibtidaiyah. SITTAH: Journal of Primary Education, 1(2), 139-148. https://doi.org/10.30762/sittah.v1i2.2487

Rani, M. (2021). Efektivitas Pembelajaran Daring Menggunakan Media Online Selama Pandemi Covid-19 Mata Pelajaran Akidah Akhlak Pada Peserta Didik Kelas IX Semester Ganjil Mtsn 2 Tanah Laut Tahun Pelajaran 2020-2021. EDUTECH : Jurnal Inovasi Pendidikan Berbantuan Teknologi, 1(1), 11.

Sari, R. P., Tusyantari, N. B., \& Suswandari, M. (2021). Dampak Pembelajaran Daring Bagi Siswa Sekolah Dasar Selama Covid-19. Prima Magistra: Jurnal Ilmiah Kependidikan, 2(1), 9-15. https://doi.org/10.37478/jpm.v2i1.732

Solong, N. P. (2021). Manajemen Pembelajaran Luring Dan Daring Dalam Pencapaian Kompetensi. TADBIR : Jurnal Manajemen Pendidikan Islam, 9, 14.

Sulha, S. (2020). Penerapan Montessori Dalam Pembelajaran Matematika Melalui Luring Sebagai Alternatif Masa Pandemi. Prismatika: Jurnal Pendidikan dan Riset Matematika, 3(1), 22-30. https://doi.org/10.33503/prismatika.v3i1.1010

Sutriyani, W. (2020). Studi Pengaruh Daring Learning Terhadap Minat Dan Hasil Belajar Matematika Mahasiswa Pgsd Era Pandemi Covid-19. Jurnal Pendidikan Dasar, 2, 11.

Turmuzi, M., \& Dasing, A. S. H. (2021). Analisis Kesulitan Belajar Mahasiswa Secara Online (E-Learning) Selama Masa Pandemi Covid-19. Edukatif: Jurnal Ilmu Pendidikan, 3(3), 11. 
Yani, Y. \& Bernarda Teting. (2020). Komparasi Hasil Belajar Mata Kuliah Patofisiologi Antara Pembelajaran Dalam Jaringan (Daring) Dengan Pembelajaran Luar Jaringan(Luring)Mahasiswa Semester Ii Stikes Dirgahayu Tahun Akademik 2019/2020. Jurnal Keperawatan Dirgahayu (JKD), 2(2), 23-31. https://doi.org/10.52841/jkd.v2i2.152

Zuraida, Z., Putri, R., Maryana, M., \& Zakaria, M. (2021). Penerapan Metode Pemberian Tugas dalam Pembelajaran PAI untuk Meningkatkan Prestasi Siswa Dimasa Pandemi Di MAS Al-Zahrah Kab.Bireuen. Jurnal Teknologi Terapan and Sains 4.0, 17. 